\title{
Assessing the effects of using compost-sludge mixtures to reduce erosion in road embankments
}

\author{
By: Juan de Oña, Francisco Osorio and Pedro A. Garcia
}

This document is a post-print versión (ie final draft post-refereeing) of the following paper:

Juan de Oña, Francisco Osorio and Pedro A. Garcia (2010) Assessing the effects of using compost-sludge mixtures to reduce erosion in road embankments. Journal of Hazardous Materials, 164, 1257-1265.

Direct access to the published version:

http://dx.doi.org/10.1016/j.jhazmat.2008.09.037 


\title{
Assessing the effects of using compost-sludge mixtures to reduce erosion in road embankments
}

\author{
J. De Oña ${ }^{1 *}$, F. Osorio ${ }^{1}$ and P. A. Garcia ${ }^{2}$ \\ ${ }^{1}$ Department of Civil Engineering; University of Granada \\ ${ }^{2}$ Department of Statistics and O.R.; University of Granada \\ ${ }^{*}$ Corresponding author's address.- Departamento de Ingeniería Civil; Universidad de Granada; \\ Campus de Fuentenueva, s/n; 18071; Granada - SPAIN; Telephone.- 34958249979; Fax.- \\ 34958246138; e-mail (corresponding author).-jdona@ugr.es
}

\begin{abstract}
Recent research shows the benefits derived from applying compost and sludge to road embankments to enhance the cover crop and reduce soil loss due to erosion, particularly in arid environments. Following this line of research, the study described in this paper analyzes and compares the use of sludge and compost for the purposes mentioned. In the first phase of this study, compost or sludge was applied separately to road embankments, and in the second phase both were applied simultaneously. This paper discusses the results obtained in each case. Our study was conducted on a total of 32 plots, located along a road embankment. The 32 plots, each with an area of $20 \mathrm{~m}^{2}$, were divided into two groups of 16 . One group was placed on a 2:1 side slope, and the other was on a 3:2 side slope. Each group received four different compost dosages $(0,40,60$ and $80 \mathrm{t} / \mathrm{ha})$ and four sludge dosages $(0,60,80$ and 100t/ha). Four plant species were selected to be planted in each plot. Our study analyzes the survival rate of the plants, their growth rate and germination, colonization of the plots by other species, cover crop per plot, and soil loss, all in relation to the compost and sludge dosage as well as the side slope type. The results obtained show that when only sludge or compost was applied to the plot, soil loss was reduced by an average of $35 \%$, whereas when a mixture of sludge and compost was applied, soil erosion was reduced by $63 \%$ to as much as $90 \%$.
\end{abstract}

Key words: arid environment, erosion, roads embankments, compost-sludge mixtures 


\section{INTRODUCTION}

The construction of new highways spoils the natural environment through which the roads pass. The damage is due, in part, to the loss of cover crop during construction and the increase in soil erosion. Such erosion is a concern on road embankments with important side slopes due to the risk of slope instability [1].

Many different measures can be taken against erosion in road embankments [1, 2, 3]: erosion control nets, open-weave geotextiles, geosynthetic mattings, erosion control blankets, loose mulches, hydromulches and chemical soil binders. Most of these are designed to absorb the kinetic energy of rainfall by minimising its contact with the soil and slowing water velocity. Vegetation has the same favourable effects, so cover crop is the most important factor against erosion $[2,4]$.

However, the characteristics of embankments are not usually suitable for plants because materials are basically selected for their geotechnical features. The materials are immature soils with poor structure and lack of nutriments, which restricts vegetation growth. Furthermore, construction sites in arid climates make revegetation more difficult.

Several studies $[2,3,5,6,7,8]$ have proved the benefit of using solid waste compost in road construction to reduce runoff and erosion. There are also a considerable number of experiences of sludge utilisation in agriculture in Europe and the USA [9, 10], but very few of sludge reuse when attempting to re-establish vegetation on road embankments $[7,11]$.

These by-products are generated in wastewater treatment plants and recycling and composting plants all over the world, but they are usually not reused.

There is a general agreement on the advantages of using compost and sludge for soil amendment and plant growth $[5,6,9,10]$, since the fertilisation capacity of these materials helps the growth of a cover crop which, in turn, reduces erosion. However, the benefits of applying sludge and compost need to be weighed against the potential hazards associated with certain sludge-borne constituents (e.g. heavy metals, organic contaminants).

Although the use of compost or sludge for revegetating highway embankments has been 
analyzed before, no research has been done on their combined use. For that reason, the present field study was undertaken to assess the effects of using compost-sludge mixtures for road embankment revegetation. The main objective of the study was to asses the benefits of using compost-sludge mixtures, as opposed to only compost or only sludge, in terms of plant growth and soil loss reduction.

\section{MATERIALS AND METHODS}

This research was conducted simultaneously to others studies intended to prove the benefits of using only sludge [11] or only compost [8] for reducing erosion on road embankments.

Therefore, the materials and methods will be described briefly, pointing to the most important parameters.

\subsection{SITE AND CLIMATIC CONDITIONS}

The field study was conducted on the side slope of a highway embankment in the Waste Recycling and Composting Plant of Gador in Almeria, in the south of Spain. This is a semi-arid environment characterized by infrequent but intense rainfalls and limited vegetation, where erosion processes have a big impact.

The area is situated between the Gador Mountains, to the west, and the Alhamilla Mountains, to the east. It is an area of many ravines and dry riverbeds. As described by Rueda [12], the climate is a typically dry Mediterranean climate. Average annual precipitation is $219 \mathrm{~mm}$, concentrated in winter and autumn, and the beginning of spring. Winds come from the westsouthwest coastal area but most of the terrain is protected by the Gador Mountains. In summer there are usually very hot winds from the east that cause major dehydrations. Winds from the north enter this area and cause temperatures close to $0{ }^{\circ} \mathrm{C}$ during some of the winter months. Maximum and minimum temperatures recorded during this study were $40{ }^{\circ} \mathrm{C}$ and $3.5^{\circ} \mathrm{C}$, with an average relative humidity of $66 \%$ [13].

\subsection{CHARACTERISTICS OF SOIL, COMPOST AND SLUDGE USED IN THE EMBANKMENT}

The fill material used in the embankments came from the previous excavation for the storage dumps in the waste plant of Gador. Complete analyses of aggregates used in the embankments were carried out (Tables 1-4). Table 1 shows soil classification, geotechnical parameters and 
some other parameters. The embankment fill materials are classified as silty sands or sand-silt mixtures (SM), using the A.S.T.M. classification, or as materials consisting predominantly of stone fragments or gravel, either with or without a well-graded soil binder (A-1-a), using the A.A.S.H.T.O. classification.

\section{(TABLE 1)}

The analysis of organic content, gypsum content, other soluble salt content and water content limit show that this aggregate was suitable for use in embankment cores in Spain [14] (Table 1). However, its agronomic characteristics (moisture content, organic matter, etc) are very poor, as shown in Table 2.

(TABLE 2)

Complete analyses of sludge and compost were mainly made to assess their fertilizing capacity and to check their heavy metals content as well as to check that their microbiological parameters do not exceed the threshold marked by legislation (Tables 2-4).

(TABLE 3)

(TABLE 4)

Table 3 shows total concentrations of heavy metals in soil, sludge and compost samples. Sludge presents the highest values for copper, zinc, mercury and chromium; and compost presents the highest values for cadmium, nickel and lead.

No current regulations on heavy metals limits exist in the EU for the usage of sludge and compost in road embankments. In the EU, these by-products have only been used for agricultural purposes. Reference is therefore made to agriculture regulations $[15,16]$. Table 3 shows that all heavy metal agricultural concentration limits for sludge are higher than concentration limits for compost. Consequently, regulations are more restrictive for compost than for sludge application in agriculture. If only sludge regulation [15] is considered, no concentration values (sludge and compost) exceed the threshold marked by legislation for heavy metal. If compost regulation [16] is considered, no values exceed the threshold marked by the legislation except for cadmium concentration. 
However, the Texas Department of Transportation, which has used compost for road embankment revegetation, has established heavy metal limits for "uncontrolled" use of compost as a soil amendment [3]. Table 3 shows these limits and all of them are higher than those obtained for the materials used during this research.

According to Table 4, the compost samples analyzed showed no traces of salmonella or clostridium perfringens and the sludge samples analyzed showed no traces of salmonella or Fecal Coli. The content of pathogenic bacteria in the compost and sludge were thus lower than the maximum values established in the 2 nd draft of the EU Directive regarding the biological treatment of biowaste and the 3rd draft of the EU Directive on sludge, respectively. Current European legislation $[15,17]$, transposed to Spanish regulation, establishes no limits for microbiological parameters in compost or sludge.

\subsection{EXPERIMENTAL PLOTS CHARACTERISTICS}

The investigation was conducted in 32 test plots measuring $4 \mathrm{~m} \times 5 \mathrm{~m}$ each. Consequently, the experiment area measured $640 \mathrm{~m}^{2}$. The 32 test plots were divided in two sets of 16 plots each to compare the influence of the embankment slope.

Two different standard embankment slopes were used: 3:2 and 2:1 side slopes are the most widely used in road embankments due to geotechnical factors. The first one (33.7ㅇ) complies with enough security requirements for a great variety of soils types, and it reduces the total surface used and the final earth-moving volume. The second (26.6ㅇ) is used mainly for security requirements with very loose unconnected materials that have very little internal friction, or for environmental reasons.

\subsection{EXPERIMENT DESIGN}

Sixteen different compost-sludge doses were used for each of the side slopes. Table 5 shows the dosages for each plot. Four doses were used for sludge (0,60, 80 and 100t/ha) and for compost $(0,40,60$ and $80 \mathrm{t} / \mathrm{ha})$, with an average thickness of $0,4.72,6.30$ and $7.87 \mathrm{~mm}$, respectively, for sludge and $0,2.33,3.49$ and $4.65 \mathrm{~mm}$, respectively, for compost.

(TABLE 5) 
The sixteen different compost-sludge dosages were obtained by combining these four doses.

Sludge doses were adopted on the basis of previous work carried out in the agriculture domain $[9,18]$. The objective in these studies was ground pollution protection. This concern is also approached in this paper. Compost doses were adopted on the basis of treatment cost, which should be approximately the same as that of the sludge treatment.

Sludge and compost were applied directly to the surface of the embankment slope; no topsoil was used.

Four different species were selected to analyze growth capacity, and to test two different planting procedures in their application: esparto (Stipa tenaccisima), thyme (Thymus capitatus), genista (Genista umbellata) and broom (Retama monosperma).

The two different planting processes were:

- Hydroseeding: It was used for esparto and thyme. Planting dosage was $2.5 \mathrm{~g} / \mathrm{m}^{2}$ for each species and a previous shelling was made before applying the seeds. The total quantity of seed was $3200 \mathrm{~g}$, for two plot series of $20 \mathrm{~m}^{2}$ each.

- Manual planting: It was used for genista and broom. The planting frame was $100 \mathrm{~cm} \mathrm{x}$ $100 \mathrm{~cm}$ and planting was triangular. In this way, no plant could have another one of its own species beside it. The total number of plants used was 20 (10 of each species) per plot. The total was 320 units of genista and 320 of broom.

\subsection{PROCESS DESIGN, EXECUTION, FOLLOW-UP AND CONTROL}

In order to be able to reproduce the experiment on any real construction site, the resources and procedures used during the experiment were the same as those that are available during highway construction.

Plots were prepared on the embankment of the road that connects the selection and sorting warehouse with the fermentation and purification warehouse at the Gador plant. A 30m length of land was left as a soft transition between both slopes (2:1 and 3:2). Thus, the total length of the experimental embankment was $158 \mathrm{~m}$ ( $4 \mathrm{~m}$ width $\times 32$ plots $+30 \mathrm{~m}$ transition).

After the plots were prepared, sludge and compost were applied manually without any kind of 
cultivating (e.g. by rotovating) prior to application. First of all dehydrated sludge, with a moisture content of $75.85 \%$, was put in place. It was a viscous and plastic-like material that was difficult to handle. Next, compost was applied. Compost was easily distributed because it is a granular material, lacking cohesion, and loose when poured out.

As manual planting required stepping on the embankment slope, broom and genista were planted first, and later esparto and thyme were hydroseeded. The only maintenance was irrigation during the first three weeks after sowing, which is the usual treatment during road construction.

Parameters measured during research were:

- Survival rate. Percentage of plants alive was recorded for genista and broom weekly.

- Plant growth. Growth percentage was recorded for genista and broom weekly. The height of every plant alive was measured manually using a standard ruler with millimetre accuracy.

- Plant germination. Germinated plants per $\mathrm{m}^{2}$ were counted for thyme and esparto fortnightly.

- Colonization by other species. Colonizing plants per $\mathrm{m}^{2}$ were counted (i.e. species that had not been planted, but had developed without control) each month.

- Crop cover per plot. It was measured by taking a digital picture of every analyzed plot.

- Erosion estimation. Erosion was calculated with the Universal Soil Loss Equation (Equation 1) [19], which is considered the basis for subsequent formulations and is recognized as the one that best approximates the physical phenomenon.

$$
A=R \cdot K \cdot L \cdot S \cdot C \cdot P
$$

where $A$ is the soil loss (t/ha.year), $R$ is the rainfall erosivity index $\left(\mathrm{J} \cdot \mathrm{cm} / \mathrm{m}^{2} \cdot \mathrm{h}\right), \mathrm{K}$ is the soil erodibility factor $\left(\mathrm{t} \cdot \mathrm{m}^{2} \cdot \mathrm{h} / \mathrm{ha} \cdot \mathrm{J} \cdot \mathrm{cm}\right), \mathrm{L}$ is the slope length (non-dimensional), $\mathrm{S}$ is the slope factor (non-dimensional), $\mathrm{C}$ is the cropping factor (non-dimensional), and $\mathrm{P}$ is the conservation practice factor (non-dimensional).

The Food and Agriculture Organization of the United Nations has developed experimental 
formulations to determine all these factors [20]. Several studies have adapted this formulation to the particular climate conditions in Spain $[21,22]$. Rainfall erosivity $(R)$, soil erodibility $(K)$, slope length $(L)$ and conservation practice factors $(P)$ were kept constant for all the plots (see Table

6). Differences in the results are due to the slope factor (S) and the cropping factor (C) obtained from the cover crop in percent [23]. C is presented in Table 7.

(TABLE 6)

(TABLE 7)

\subsection{STATISTICAL METHODS}

The statistical analysis of the results was performed by means of Analysis of Variance (ANOVA), on a quantitative dependent variable and independent variables (factors). Analysis of variance is used to test the hypothesis that several means are not the same. In our analyses we performed several two and three factor ANOVA for different response variables. In addition to determining that differences between the means exist, several post-hoc LSD tests were considered on factor levels. Interactions between factors were considered, in order to determine if the presence/absence of a factor level increases/decreases the effect on the response variable. Study of Residuals and Bartlett tests were performed for checking assumptions of normality and homoscedasticity, respectively [24, 25]. Calculations were performed using Rstatistical program (R Development Core Team 2005) [26].

\section{RESULTS AND DISCUSSION}

A three-way ANOVA (factors slope type-compost-sludge) was performed to analyze genista and broom growth for each factor. To analyze the other variables (survival rate, germination, colonization, cover crop and soil loss) a two-way ANOVA was performed (factors slope typecompost and factors slope type-sludge), since there were no replicates per plot. Thus, in this case, the focus of the statistical analysis is to ascertain whether the effects produced by different sludge or compost dosages vary according to embankment slope type.

\subsection{SURVIVAL RATE}

There were no statistically significant differences ( $p>0.05$; LSD test) on the survival rate of each 
plant species (genista and broom) in any comparisons between the factors' levels. Table 8 shows the means for different factor levels. These results are clearly due to high variability for the survival rates (values ranging from $10 \%$ to $90 \%$ for genista and ranging from $30 \%$ to $100 \%$ for broom), with high and low values shuffled randomly in each factor level. Table 8 (columns 2 , 3) shows the average genista and broom survival rate values for the different compost and sludge dosages. Figure 1 shows all the results for every plot, that is to say, from plot 1 to 32 where $\mathrm{n}$ is the number of survival plants per plots.

(TABLE 8)

(FIGURE 1)

\subsection{PLANT GROWTH}

The final average height of the genista was $48.00 \mathrm{~cm}$, whereas the height of the broom was $51.70 \mathrm{~cm}$ (Table 8). For both species, average height at the time of planting was $25 \mathrm{~cm}$, with S.D. 1.21 for genista and S.D. 1.19 for broom.

Performed three-way ANOVA, to analyze genista and broom growth by slope type, compost and sludge as factors, shows that there were significant differences between the considered levels for these principal factors. Interaction analysis of principal factors identified statistical significance for the three two-factor interactions and non-significance for the three-factor interaction.

More precisely, Table 8 (columns 4,5 ) shows the results for the analysis of the principal factors related to the average genista and broom growth values. The genista grew higher on the 2:1 slope $(50.59 \mathrm{~cm})$ than on the $3: 2$ slope $(45.41 \mathrm{~cm})$. In contrast, the broom grew slightly higher on the $3: 2$ slope $(52.40 \mathrm{~cm})$ than on the $2: 1$ slope $(51.00 \mathrm{~cm})$. In both cases, the LSD test shows that side slope type has a statistically significant $(p<0.05)$ effect on the growth of both plant species.

Also, the LSD test shows that compost dosage has a statistically significant $(p<0.05)$ effect on the growth rate of both plant species. For the genista, two different groups were identified: (1) plots that received a compost dosage of 80t/ha; (2) other dosages, with non-significant differences between each other. For broom, there were also two different groups: (1) plots with 
no compost; (2) all other plots where compost was applied, with non-significant differences between them.

For both species the LSD test shows that the sludge dosage has a statistically significant $(p<0.05)$ effect on the growth rate. For genista, two different groups were identified: $(1)$ plots that received a sludge dosage of 60t/ha; (2) plots where other dosages were applied, with nonsignificant differences between them. For broom, three different groups were identified: (1) plots that received a sludge dosage of 60 and $80 \mathrm{t} /$ ha, producing the maximum growth rate; (2) plots that received a sludge dosage of 100t/ha; (3) plots that received no sludge, producing the minimum growth rate.

Several two-factor interaction analyses were performed to study the joint effect of the principal factors. In the case of the joint effect of side slope type and compost dosage on the genista growth rate the analysis shows that the interaction between the factors is statistically significant $(p<0.05)$. The 2:1 slope reduces the effect of the compost, and the 3:2 slope increases it. For the joint effect of side slope type and sludge dosage on the genista growth rate, the interaction between the factors is also statistically significant $(p<0.05)$. However, here it is the $3: 2$ slope that reduces the effect of the sludge, whereas the 2:1 slope increases it. Regarding the joint effect of compost and sludge dosage on the genista growth rate, the interaction of factors is also statistically significant $(p<0.05)$. When compost dosages of $0 t /$ ha (whose behaviour is very irregular) are excluded, the results obtained show that sludge and compost produce the highest growth rate when the compost dosage applied is $80 \mathrm{t} / \mathrm{ha}$.

For broom, the joint effect of side slope type and compost dosage clearly shows that the interaction between both is statistically significant $(p<0.05)$. More specifically, the $3: 2$ slope reduces the effect of the compost, and the 2:1 slope increases it. In the joint effect of side slope type and sludge dosage on the broom growth rate, the interaction between these factors is statistically significant $(p<0.05)$. Whereas the 3:2 slope reduces the effect of sludge, the $2: 1$ slope increases it. In the joint effect of compost and sludge dosage on the broom growth rate, the interaction between the factors is statistically significant $(p<0.05)$. The results of high dosages of compost (60 and 80t/ha) are similar with non-significant differences. However, in our study, the best results were obtained when average dosages of sludge (60 and $80 \mathrm{t} / \mathrm{ha}$ ) were 
applied, whereas just the opposite was the case for low compost dosage (40t/ha). The plants grew the highest with no sludge at all or with an extremely high sludge dosage (0t/ha or 100t/ha). Plots where no compost was applied had the lowest growth rate $(42.81 \mathrm{~cm})$.

\subsection{PLANT GERMINATION}

Thyme had an average germination of $1.75 \mathrm{plants} / \mathrm{m}^{2}$, while esparto had an average germination of 0.50 plants $/ \mathrm{m}^{2}$. The fact that the value for esparto is considerably lower than the value for thyme seems to indicate that thyme is more suitable than esparto for hydroseeding in this particular area in southern Spain.

Table 8 shows means for different factor levels. Table 8 also shows (columns 6,7 ) the average thyme and esparto germination values for the different compost and sludge dosages. Table 9 shows all the results for every plot, that is to say, from plot 1 to 32 .

\section{(TABLE 9)}

The LSD test shows that the side slope type has a statistically significant $(p<0.05)$ effect on the germination of both plant species. However, the same test shows that compost dosage does not have a statistically significant ( $p>0.05$ ) effect on thyme and esparto germination.

The two-factor ANOVA to study the joint effect of side slope type and compost dosage on thyme and esparto germination indicates that the interaction between these factors is not statistically significant $(p>0.05)$.

The LSD test shows that the sludge dosage has a statistically significant $(p<0.05)$ effect on thyme and esparto germination. For thyme, two different groups can be identified: (1) plots with sludge dosages of 100t/ha and 60t/ha, which give the highest germination rate; (2) plots with 0t/ha, which give the lowest germination rate. Between these two extremes there are plots with $80 t / h a$ whose differences are not statistically significant $(p>0.05)$ when compared to either of the above-mentioned groups. For esparto, two different groups can also be identified: (1) plots with no sludge, which give the highest germination rate; (2) plots with different sludge dosages, where the germination rate was the lowest, with non-significant differences between each other. The two-factor ANOVA to study the joint effect of side slope type and sludge dosage on esparto 
germination shows that the interaction between these factors is not statistically significant $(p>0.05)$. However, in the case of thyme, their interaction is statistically significant $(p<0.05)$. According to our results, the 3:2 slope reduces the effect of the sludge, whereas the 2:1 slope increases the effect produced.

\subsection{COLONISATION BY OTHER SPECIES}

The plant species used in the experiment (genista, broom, thyme and esparto) competed with the colonizing species for space, water and nutrients as a cover crop for the plots.

(TABLE 10)

Table 10 shows means for different factor levels.

The LSD test shows that side slope type has a statistically significant $(p<0.05)$ effect on natural colonization by other plant species. However, the LSD test shows that compost dosage does not have a statistically significant $(p>0.05)$ effect on colonization. The same test shows that sludge dosage has a statistically significant $(p<0.05)$ effect on colonization. In this respect, three different groups can be identified: (1) plots with a sludge dosage of $60 t /$ ha with the highest colonization rate; (2) plots with a dosage of 80 and 100t/ha with a medium colonization rate; (3) plots with a dosage of $0 \mathrm{t} / \mathrm{ha}$ with the lowest colonization rate.

The highest levels of colonization were achieved with mixtures of sludge and compost (dosages 8-16), whereas compost dosages with no sludge (dosages 5,6 , and 7) show lower values of colonization by other species (see Table 9).

The two-factor ANOVA to study the joint effect of side slope type and compost, and of side slope type and sludge on natural colonization by other plant species shows that the interaction between these two factors is not statistically significant $(p>0.05)$.

\subsection{CROP COVER}

Table 10 shows the means for different factor levels.

The LSD test shows that slope type has a statistically significant $(p<0.05)$ effect on the cover crop. The LSD test also shows that compost dosage has a statistically significant $(p<0.05)$ effect on the cover crop. Two different groups can be identified: (1) plots with no compost; (2) plots 
with compost, with non-significant differences between each other.

This same test shows that sludge dosage has a statistically significant $(p<0.05)$ effect on the cover crop. Two different groups can be identified: (1) plots with no sludge; (2) plots with sludge, with non-significant differences between them.

As shown in our experiment (see Tables 9 and 10), the highest cover crop levels were achieved with mixtures of sludge and compost $(8-16)$, whereas sludge dosages with no compost $(2,3$, and 4$)$ or compost dosages with no sludge $(5,6$, and 7$)$ produce lower cover crop values. The two-factor ANOVA to study the joint effect of side slope type and compost, and of side slope type and sludge on the cover crop clearly shows that the interaction between these factors is not statistically significant $(p>0.05)$.

\subsection{SOIL LOSS}

A dense cover crop produces a lower rate of soil loss. In our experiment, the lowest soil loss values were obtained in plots where mixtures of sludge and compost were applied. This was the case for both slope types.

Table 10 shows the means for different factor levels. Table 9 shows all the results for plot 1 to 32. The LSD test shows that slope type is not statistically significant ( $p>0.05)$. Thus, Figure 2 represents 16 dosages (bar height represents the mean for 2:1 and 3:2 slope soil loss data) and shows that plots that received a compost dosage had a lower soil loss rate than plots where no compost was applied. LSD test shows that compost dosage has a statistically significant $(p<0.05)$ effect on soil loss. Two different groups can be identified: (1) plots with no compost; (2) plots with compost, with non-significant differences between each other.

\section{(FIGURE 2)}

The same conclusion could be arrived at for sludge dosage: a lower percentage of soil loss than where no sludge was applied and two different groups can be identified: (1) plots with no sludge; (2) plots with sludge, with non-significant differences between them.

Figure 2 shows that the lowest levels of soil loss were achieved with sludge-compost mixtures, whereas sludge dosages with no compost or compost dosages with no sludge show higher 
levels of soil loss. Dosage 1 (with no sludge or compost) produces the highest soil loss value. The two-factor ANOVA indicates that there is no interaction $(p>0.05)$ for the joint effect on soil loss of side slope type and compost dosage, and side slope type and sludge dosage.

The results of our study also shows that despite the fact that compost initially inhibits the germination of plant species, afterwards it protects the slope against erosion more effectively since it produces a lower level of soil loss than sludge does.

Another interesting fact is that for a given compost dosage (e.g. 40t/ha and 60t/ha), soil loss is reduced as the sludge dosage decreases (from 100 to $60 \mathrm{t} / \mathrm{ha}$ ). However, this is not the case for a compost dosage of $80 t / h a$, where the minimum soil loss value is minimal when it is applied with the maximum sludge dosage (100t/ha).

\section{CONCLUSIONS AND RECOMMENDATIONS}

The conclusions that can be derived from this experimental study are:

- In the semi-arid environment of the Sierra de Gador in Almeria (Spain), broom is a more suitable species than genista for manual planting, and thyme is more suitable than esparto for hydroseeding.

- Slope type is not a statistically significant factor $(p>0.05)$ for the survival of genista and broom though it does affect their growth rate. For example, genista grew higher on the 2:1 slope and broom grew higher on the 3:2 slope. Slope type also has an impact on thyme and esparto germination. More specifically, the 2:1 slope produced better results in this respect than the 3:2 slope.

- Compost hampers the germination and survival rate of all of the species planted as well as the colonizing plants, even though it subsequently enhances their growth. The application of sludge enhances the germination of thyme and colonizing species as well as the growth rate of genista and broom. However, it hampers the survival of genista and broom as well as the germination of esparto. The growth rate of genista and broom increases as the compost dosage increases. In our study, the maximum growth rate for genista and broom was obtained with a sludge dosage of $60 t / h a$.

- Colonization by other species plays an important role in increasing cover crop, and 
thus, in reducing soil loss by erosion. Sludge and compost are the source of the germinative seeds that cause natural colonization by other species because the seeds are already inside the sludge and compost dosage applied.

- The minimum cover crop (18.8\%) and the greatest soil loss (71.5t/ha per year) occurred in plots that received neither sludge nor compost.

- Higher compost dosages produced a denser cover crop and a lower rate of soil loss. In the case of sludge, the lowest soil loss occurred, on average, in plots with a sludge dosage of $60 \mathrm{t} / \mathrm{ha}$.

- Treatments that only use sludge or compost reduce soil loss by an average of approximately $35 \%$. In contrast, treatments with mixtures of sludge and compost can reduce erosion from $63 \%$ to as high as $90 \%$.

On the basis of the results obtained, and with a view to reducing soil loss, the sludge-compost mixtures worked better than the usage of sludge only or compost only. The same conclusion can be inferred with regards to improving the rate of plant growth, although in this case the tendency can be observed but the differences are not statistically significant.

The best dosage to apply is $60 \mathrm{t} / \mathrm{ha}$ of sludge and $40 \mathrm{t} / \mathrm{ha}$ of compost (dosage 16 ). It provides a maximum plant growth and a minimum soil loss of $7.50 \mathrm{t} /$ ha per year. However, if it is a matter of using the highest quantity of waste, a dosage of $100 \mathrm{t} /$ ha of sludge and $80 \mathrm{t} / \mathrm{ha}$ of compost is the best choice.

Besides reducing soil loss, these mixtures also produce higher plant growth rates, and enhance natural colonization by other plant species.

Consequently, our study shows that even though the use of sludge or compost on road embankments helps to reduce soil loss, as shown in recent research studies $[2,3,5,6,7,8$, $11]$, the joint use of both types of bio-solids produces even better results.

\section{ACKNOWLEDGEMENTS}

The research team would like to thank Dr. Antonio López Navarro and Dr. Ernesto Hontoria for their personal contribution to this project. The authors appreciate the reviewers' comments and 
effort in order to improve the paper.

\section{REFERENCES}

[1] J. Grace, Erosion control techniques on forest road cutslopes and fillslopes in north Alabama, Transport. Res. Rec. 1652 (1999) 227-324.

[2] D. Block, Controlling erosion from highway projects, Biocycle 41 (1) (2000) 59-62.

[3] B.B. Storey, J.A. McFalls, S.H. Godfrey, The use of compost and shredded brush on rightsof-way for erosion control, Research Report 1352-2F, Texas Transportation Institute, College Station, TX, 1996.

[4] R. Morgan, Erosión y conservación del suelo, Mundi-Prensa, Madrid, 1997.

[5] R. Persyn, T. Glanville, T. Richard, J. Laflen, P. Dixon, Environmental effects of applying composted organics to new highway embankments. Part 1. Interrill runoff and erosion, Trans. ASAE 47 (2) (2004) 463-469.

[6] S. Benik, B. Wilson, D. Biesboer, B. Hansen, D. Stenlund, Performance of erosion control products on a highway embankment, Trans. ASAE 46 (4) (2003) 1113-1119.

[7] J. De Oña, F. Osorio, Using waste to reduce slope erosion on road embankments, Proceedings of the Institution of Civil Engineers, Transport, 159 (2006) 15-24.

[8] F. Osorio, J. De Oña, Application of Compost from Urban Solid Wastes in Road's Embankments, J. Environ. Sci. Health, Part A, 41 (2006) 2311-2327.

[9] A. Andreadakis, D. Mamais, E. Gavalaki, S. Kampylafka, Sludge utilization in agriculture: possibilities and prospects in Greece, Water Sci. Technol. 46 (10) (2002) 231-238.

[10] M. Aziz, L. Koe, Potential utilization of sewage-sludge, Water Sci. Technol. 22 (12) (1990) 277-285.

[11] J. De Oña, F. Osorio, Application of sludge from urban wastewater plants in road's embankments, Journal of Hazardous Materials, B131 (2006) 37-45.

[12] F. Rueda, Ecosistema de la vega del bajo Andarax, Confederación Española de Cajas de Ahorro, Madrid, 1987. 
[13] Las Palmerillas Meteorological Station, http://www.laspalmerillas.cajamar.es, 2003 (meteorological daily data from 1976).

[14] Ministerio de Fomento. PG-3. Pliego de Prescripciones Técnicas Generales para Obras de Carreteras y Puentes, 1st ed., Madrid, Spain, 1976.

[15] Council Directive of 12 June 1986 on the protection of the environment, and in particular of the soil, when sewage sludge is used in agriculture (86/278/EEC).

[16] Ministerio de Agricultura, Pesca y Alimentación. Orden de 28 de Mayo de 1998 sobre fertilizantes y afines, Madrid, 1998 (transposed European Legislation).

[17] Council Directive of 18 December 1975 on the approximation of the laws of the Member States relating to fertilizers $(76 / 116 / E E C)$.

[18] F. Amlinger, B. Gotz, P. Dreher, J. Geszti, C. Weissteiner, Nitrogen in biowaste and yard waste compost: dynamics of mobilisation and availability, Eur. J. Soil Biol. 39 (3) (2003) 107116.

[19] U.S. Department of Agriculture, Agriculture Handbook 282, 1958.

[20] United Nations FAO, Guidelines for Soil Profile Description. Food and Agriculture Organization, 3rd ed., 1990, p. 90.

[21] M. González, La Ecuación Universal de Pérdidas de Suelo. Pasado, presente y futuro. Ecología 5 (1991) 7-28.

[22] ICONA, Agresividad de la lluvia en España. Valores del Factor R de la Ecuación Universal de Pérdidas de Suelo, Madrid, Spain, 1988.

[23] J. Aguilo, Tratado del medio natural. Causas de destrucción del suelo, Tomo I, Ed. UPM, CEOTMA, INIA e ICONA, Madrid, Spain, 1981, pp. 499-559.

[24] V. Abraira, A. Pérez, Métodos Multivariantes en Bioestadística, Centro de Estudios Ramón Areces, Madrid, Spain, 1996.

[25] R.H. Myers, D.C. Montgomery, G.G. Vining, Generalized Linear Models, With Applications in Engineering and the Sciences, John Wiley \& Sons, Inc., New York, 2002. 
[26] R Development Core Team, R: A language and environment for statistical computing, $R$ Foundation for Statistical Computing, Vienna, Austria, 2006, URL http://www.R-project.org. 


\section{Figures legends}

Figure 1. Averaged Growth for Genista and Broom, in relation to slope and dosage

Figure 2. Soil loss in relation to dosage

Tables legends

Table 1. Summary of properties of embankment fill materials

Table 2. Different characteristic parameters in soil, compost and sludge samples

Table 3. Heavy metals in soil, sludge and compost samples, and maximum admitted values for use in agriculture

Table 4. Checking of pathogenic bacteria in sludge and compost

Table 5. Sludge and compost dosage in the experiment for each of the side slopes

Table 6. Factors R, K, L, S and P.

Table 7. C factors related to the cover crop percentage

Table 8. Survival rate, growth and germination vs. slope, compost and sludge dosage.

Table 9. Germination, colonisation, crop cover and soil loss vs. compost-sludge mixture.

Table 10. Colonisation, crop cover and soil loss vs. slope, compost and sludge dosage. 
Table 1. Summary of properties of embankment fill materials

\begin{tabular}{|c|c|c|c|}
\hline \multicolumn{4}{|l|}{ Soil classifications } \\
\hline & $\begin{array}{l}\text { Group and } \\
\text { subgroup }\end{array}$ & \multicolumn{2}{|c|}{ Description } \\
\hline A.S.T.M. & SM & \multicolumn{2}{|c|}{$\begin{array}{l}\text { Silty sands, sand-silt mixtures. More than } \\
50 \% \text { passes No. } 4 \text { sieve. More than } 50 \% \\
\text { retained on No. } 200 \text { sieve. }\end{array}$} \\
\hline A.A.S.H.T.O. & A-1-a & \multicolumn{2}{|c|}{$\begin{array}{l}\text { Materials consisting predominantly of stone } \\
\text { fragments or gravel, either with or without a } \\
\text { well graded soil binder. This soils have } \\
\text { high strength (friction angles higher than } 34 \\
\text { degrees) }\end{array}$} \\
\hline \multicolumn{4}{|l|}{ Geotechnical parameters } \\
\hline Internal friction angle & \multicolumn{3}{|l|}{$42.20^{\circ}$} \\
\hline Cohesion & \multicolumn{3}{|l|}{$5 t / m^{2}$} \\
\hline \multicolumn{4}{|l|}{ Other parameters } \\
\hline & \multicolumn{2}{|c|}{ Obtained values } & Limits $\left(^{*}\right)$ \\
\hline Organic material content & \multicolumn{2}{|l|}{$0.32 \%$} & $<2 \%$ \\
\hline Gypsum content & \multicolumn{2}{|l|}{$0.41 \%$} & $<5 \%$ \\
\hline Other soluble salt content & \multicolumn{2}{|l|}{$0.42 \%$} & $<1 \%$ \\
\hline Liquid limit & \multicolumn{2}{|l|}{$30.2 \%$} & $<65 \%$ \\
\hline \multicolumn{4}{|c|}{$\left({ }^{\star}\right)$ Maximum values for soils suitable for use in embankment cores in Spain [14] } \\
\hline
\end{tabular}


Table 2. Different characteristic parameters in soil, compost and sludge samples

\begin{tabular}{|c|c|c|c|}
\hline Parameter & Soil & Compost & Sludge \\
\hline Moisture content (\%) & 1.97 & 6.03 & 75.85 \\
\hline Real Density (g/mL) & 2.76 & 1.72 & 1.27 \\
\hline Apparent Density (g/mL) & 1.38 & 0.46 & 0.54 \\
\hline $\mathrm{pH}$ & 8.61 & 6.74 & 7.26 \\
\hline Organic Matter (\%) & 0.32 & 34.43 & 9.92 \\
\hline Dry Matter (\%) & 98.03 & 93.97 & 24.15 \\
\hline Conductivity $(\mu \mathrm{s} / \mathrm{cm})$ & 4.20 & 30.9 & 11.59 \\
\hline Humic Extract (\%) & 0.06 & 18.51 & 3.28 \\
\hline Humic Acids (\%) & 0.02 & 9.83 & 1.06 \\
\hline Fulvic Acids (\%) & 0.04 & 8.99 & 2.22 \\
\hline C:N Ratio & 4.95 & 12.69 & 2.26 \\
\hline Iron (mg/kg) & 2.00 & 222.4 & 106.57 \\
\hline Total Nitrogen (mg/kg) & 650.98 & 10965.7 & 99151.9 \\
\hline Nitrogen-Nitric (mg/L) & 10.75 & $<0.5$ & $<0.5$ \\
\hline Nitrogen-ammoniacal (mg/L) & 5.18 & 210.47 & 378.47 \\
\hline Phosphorous-P2O5 (mg/L) & 6.84 & $<1.88$ & 100.63 \\
\hline Potassium-K2O (mg/L) & 20.8 & 4248.8 & 377.50 \\
\hline Sulphate $(\mathrm{mg} / \mathrm{L})$ & 533.98 & 4234.89 & 4376.46 \\
\hline Calcium-CaO (mg/L) & 98.9 & 4036.9 & 315.6 \\
\hline Magnesium-MgO (mg/L) & 122.8 & 1154.1 & 527.1 \\
\hline Sodium- (mg/L) & 654.1 & 4228 & 601.5 \\
\hline
\end{tabular}


Table 3. Heavy metals in soil, sludge and compost samples, and maximum admitted values for use in agriculture

\begin{tabular}{|c|c|c|c|c|c|c|c|c|}
\hline \multicolumn{2}{|c|}{ Values in $\mathrm{mg} / \mathrm{kg}$} & Cadmium & Cooper & Nickel & Lead & Zinc & Mercury & Chromium \\
\hline \multicolumn{2}{|c|}{ Soil } & 2.28 & $<1$ & 2.52 & 9.93 & $<0.5$ & 0.21 & 4.19 \\
\hline \multirow{2}{*}{ Sludge } & Value & 3.82 & 230.50 & 19.10 & 38.66 & 577.00 & 8.59 & 23.23 \\
\hline & EU Limit $\left(^{*}\right)$ & 40 & 1750 & 400 & 1200 & 4000 & 25 & 1500 \\
\hline \multirow{3}{*}{ Compost } & Value & 15.23 & 16.78 & 67.66 & 118.11 & 149.59 & 1.81 & 12.25 \\
\hline & EU Limit $\left(^{+}\right)$ & 3 & 450 & 120 & 150 & 1100 & 5 & 270 \\
\hline & US Limit $\left({ }^{\#}\right)$ & 85 & 4300 & 420 & 840 & 7500 & 57 & 3000 \\
\hline \multicolumn{9}{|c|}{$\left(^{*}\right)$ EU Regulations [15] $\left(^{+}\right)$EU Regulations [16] (\#) US Regulations [3] } \\
\hline \multicolumn{9}{|c|}{ Analytical techniques: ISO 11466-ISO11047-prEN13346 } \\
\hline
\end{tabular}


Table 4. Checking of pathogenic bacteria in sludge and compost

\begin{tabular}{|c|c|c|c|}
\hline \multicolumn{4}{|c|}{ Compost } \\
\hline & \multicolumn{2}{|c|}{ Maximum admitted values } & \multirow{2}{*}{$\begin{array}{c}\text { Sample } \\
\text { Concentratior }\end{array}$} \\
\hline & $\begin{array}{c}\text { Directive } \\
\text { 76/116/EEC }\end{array}$ & $\begin{array}{c}\text { European Directive on the biological } \\
\text { treatment of biowaste, } 2^{\text {nd }} \text { Draft }\end{array}$ & \\
\hline Salmonella & $\begin{array}{l}\text { No established } \\
\text { limit }\end{array}$ & $\begin{array}{l}\text { Absent in } 50 \mathrm{~g} \text { of compost/digestate } \\
\text { (under review) }\end{array}$ & Absence \\
\hline $\begin{array}{l}\text { Clostridium } \\
\text { perfringens }\end{array}$ & $\begin{array}{l}\text { No established } \\
\text { limit }\end{array}$ & $\begin{array}{l}\text { Absent in } 1 \mathrm{~g} \text { of compost/digestate } \\
\text { (under review) }\end{array}$ & Absence \\
\hline \multicolumn{4}{|c|}{ Sludge } \\
\hline & \multicolumn{2}{|r|}{ Maximum admitted values } & \multirow{2}{*}{$\begin{array}{c}\text { Sample } \\
\text { Concentration }\end{array}$} \\
\hline & $\begin{array}{c}\text { Directive } \\
\text { 86/278/EEC }\end{array}$ & $3^{\text {rd }}$ Directive Draft ${ }^{a}$ & \\
\hline Salmonella & $\begin{array}{l}\text { No established } \\
\text { limit }\end{array}$ & $\begin{array}{l}\text { To be considered an advanced } \\
\text { treatment: Absence in } 50 \mathrm{~g} \text { (wet } \\
\text { weight) in treated sludge }\end{array}$ & Absence \\
\hline Fecal coli & $\begin{array}{l}\text { No established } \\
\text { limit }\end{array}$ & $\begin{array}{l}\text { To be considered an advanced } \\
\text { treatment: }<500 \text { Escherichia coli } \\
\text { CFU/g in treated sludge and at least } \\
6 \log _{10} \text { reduction } \\
\text { To be considered a conventional } \\
\text { treatment: At least } 2 \log _{10} \text { reduction }\end{array}$ & $<10$ \\
\hline
\end{tabular}

${ }^{a}$ There are no established limits for the pathogenic bacteria in the sludge to be applied. The limits are only used to determine the type of treatment applied to the sludge in the wastewater treatment plant. This is important in order to define authorized uses for the sludge. 
Table 5. Sludge and compost dosage in the experiment for each of the side slopes

\begin{tabular}{|l|l|l|l|l|l|l|l|l|l|l|l|l|l|l|l|l|}
\hline Dosage $\mathrm{n}^{\circ}$ & 1 & 2 & 3 & 4 & 5 & 6 & 7 & 8 & 9 & 10 & 11 & 12 & 13 & 14 & 15 & 16 \\
\hline $\begin{array}{l}\text { Sludge (t/ha) } \\
\text { Compost } \\
\text { (t/ha) }\end{array}$ & 0 & 0 & 0 & 0 & 80 & 60 & 40 & 80 & 60 & 40 & 80 & 60 & 40 & 80 & 60 & 40 \\
\hline
\end{tabular}


Table 6. Factors $R, K, L, S$ and $P$.

\begin{tabular}{|c|c|c|c|c|c|}
\hline \multirow{2}{*}{$\mathbf{R}$} & \multirow{2}{*}{$\mathbf{K}$} & $\mathbf{L}$ & \multicolumn{2}{|c|}{$\mathbf{S}$} & \multirow{2}{*}{$\mathbf{P}$} \\
\cline { 4 - 5 } & & & $\mathbf{2 H} / \mathbf{1 V}$ & $\mathbf{3 H} / \mathbf{1 V}$ & \\
\hline 51.10 & & & & \\
\hline
\end{tabular}


Table 7. $C$ factors related to the cover crop percentage

\begin{tabular}{|c|c|c|c|c|c|}
\hline Coverage \% & C & Coverage \% & C & Coverage \% & C \\
\hline 5 & 0.807 & 35 & 0.129 & 65 & 0.017 \\
\hline 10 & 0.613 & 40 & 0.086 & 70 & 0.012 \\
\hline 15 & 0.466 & 45 & 0.065 & 75 & 0.009 \\
\hline 20 & 0.319 & 50 & 0.045 & 80 & 0.006 \\
\hline 25 & 0.242 & 55 & 0.034 & 90 & 0.003 \\
\hline 30 & 0.166 & 60 & 0.023 & 100 & 0.001 \\
\hline
\end{tabular}


Table 8. Survival rate, growth and germination vs. slope, compost and sludge dosage.

\begin{tabular}{|c|c|c|c|c|c|c|}
\hline & \multicolumn{2}{|c|}{ Survival rate } & \multicolumn{2}{|l|}{ Growth } & \multicolumn{2}{|c|}{ Germination } \\
\hline & $\begin{array}{l}\text { Genista } \\
\%\end{array}$ & $\begin{array}{l}\text { Broom } \\
\%\end{array}$ & $\begin{array}{l}\text { Genista } \\
\mathrm{cm}\end{array}$ & $\begin{array}{l}\text { Broom } \\
\mathrm{cm}\end{array}$ & $\begin{array}{l}\text { Thyme } \\
\text { plants } / \mathrm{m}^{2}\end{array}$ & $\begin{array}{l}\text { Esparto } \\
\text { plants } / \mathrm{m}^{2}\end{array}$ \\
\hline Average & 51.25 & 71.25 & 48.00 & 51.70 & 1.75 & 0.50 \\
\hline \multicolumn{7}{|l|}{ Slope } \\
\hline $2: 1$ & 50.00 & 71.88 & 50.59 a & $51.00 \mathrm{a}$ & $2.99 \mathrm{a}$ & $0.70 \quad \mathrm{a}$ \\
\hline $3: 2$ & 52.50 & 70.63 & $45.41 \mathrm{~b}$ & $52.40 \quad b$ & $0.51 \mathrm{~b}$ & $0.30 \mathrm{~b}$ \\
\hline \multicolumn{7}{|l|}{ Compost } \\
\hline 0 & 55.00 & 83.75 & $47.00 \quad \mathrm{a}$ & $42.81 \quad \mathrm{a}$ & 2.61 & 0.60 \\
\hline 40 & 52.50 & 73.75 & $45.88 \quad \mathrm{a}$ & $54.13 \mathrm{~b}$ & 1.63 & 0.43 \\
\hline 60 & 50.00 & 60.00 & $47.56 \quad \mathrm{a}$ & $55.38 \quad b$ & 1.29 & 0.43 \\
\hline 80 & 47.50 & 67.50 & $51.56 \mathrm{~b}$ & $54.48 \quad b$ & 1.46 & 0.55 \\
\hline \multicolumn{7}{|l|}{ Sludge } \\
\hline 0 & 56.25 & 82.50 & $46.13 \mathrm{a}$ & $47.75 \quad \mathrm{a}$ & $0.64 \mathrm{a}$ & $0.80 \mathrm{a}$ \\
\hline 60 & 45.00 & 70.00 & $52.44 \quad b$ & $54.00 \mathrm{~b}$ & $2.28 \mathrm{~b}$ & $0.48 \mathrm{~b}$ \\
\hline 80 & 53.75 & 65.00 & $45.94 \quad \mathrm{a}$ & $53.42 \mathrm{~b}$ & $1.49 a, b$ & $0.31 \mathrm{~b}$ \\
\hline 100 & 50.00 & 67.50 & $47.50 \quad \mathrm{a}$ & $51.63 \mathrm{c}$ & $2.59 \mathrm{~b}$ & $0.41 \mathrm{~b}$ \\
\hline
\end{tabular}

Levels of the same factor without letter mean that the differences are statistically non-significant. $a, b, c$ : denotes differences statistically significant $(p<0.05)$. Two or more levels with the same letter denote a homogeneous subgroup. 
Table 9. Germination, colonisation, crop cover and soil loss vs. compost-sludge mixture.

\begin{tabular}{|c|c|c|c|c|c|c|c|}
\hline \multirow[b]{2}{*}{$\begin{array}{c}\text { Plot } \\
\text { number }\end{array}$} & \multirow[b]{2}{*}{ Slope } & \multirow{2}{*}{$\begin{array}{c}\text { Dosage } n^{\circ} \\
\text { (Table 5) }\end{array}$} & \multicolumn{2}{|c|}{ Germination } & \multirow{2}{*}{$\begin{array}{c}\text { Colonisa } \\
\text { tion } \\
\text { plant } / \mathrm{m}^{2}\end{array}$} & \multirow{2}{*}{$\begin{array}{c}\text { Crop } \\
\text { cover } \\
\% \\
\end{array}$} & \multirow{2}{*}{$\begin{array}{l}\text { Soil loss } \\
\text { t/ha.year }\end{array}$} \\
\hline & & & $\begin{array}{l}\text { Thyme } \\
\text { plant } / \mathrm{m}^{2}\end{array}$ & $\begin{array}{l}\text { Esparto } \\
\text { plant } / \mathrm{m}^{2}\end{array}$ & & & \\
\hline $\mathrm{P} 1$ & $2: 1$ & 1 & 0.0 & 0.4 & 0.3 & 12.2 & 72 \\
\hline $\mathrm{P} 2$ & $2: 1$ & 2 & 7.1 & 1.1 & 1.3 & 19.3 & 53 \\
\hline P3 & $2: 1$ & 3 & 4.3 & 0.5 & 1.4 & 12.8 & 67 \\
\hline P4 & $2: 1$ & 4 & 6.5 & 1.0 & 2.3 & 15.2 & 57 \\
\hline P5 & $2: 1$ & 5 & 2.4 & 1.4 & 1.6 & 22.5 & 47 \\
\hline $\mathrm{P} 6$ & $2: 1$ & 6 & 0.6 & 1.2 & 1.3 & 16.0 & 61 \\
\hline $\mathrm{P} 7$ & $2: 1$ & 7 & 1.4 & 1.6 & 1.2 & 17.7 & 57 \\
\hline P8 & $2: 1$ & 8 & 5.5 & 0.7 & 2.9 & 44.3 & 14 \\
\hline P9 & $2: 1$ & 9 & 2.9 & 0.5 & 2.0 & 30.4 & 31 \\
\hline $\mathrm{P} 10$ & $2: 1$ & 10 & 4.3 & 0.3 & 1.8 & 22.2 & 45 \\
\hline $\mathrm{P} 11$ & $2: 1$ & 11 & 2.1 & 0.6 & 2.3 & 37.0 & 30 \\
\hline $\mathrm{P} 12$ & $2: 1$ & 12 & 2.7 & 0.3 & 2.6 & 35.9 & 26 \\
\hline P13 & $2: 1$ & 13 & 2.2 & 0.5 & 4.0 & 42.5 & 18 \\
\hline P14 & $2: 1$ & 14 & 1.4 & 0.4 & 4.6 & 49.2 & 10 \\
\hline P15 & $2: 1$ & 15 & 1.9 & 0.3 & 4.8 & 53.3 & 8 \\
\hline P16 & $2: 1$ & 16 & 2.5 & 0.4 & 5.4 & 58.6 & 3 \\
\hline $\mathrm{P} 17$ & $3: 2$ & 1 & 0.0 & 0.6 & 6.1 & 25.3 & 71 \\
\hline P18 & $3: 2$ & 2 & 0.3 & 0.3 & 5.1 & 38.4 & 48 \\
\hline P19 & $3: 2$ & 3 & 0.6 & 0.4 & 4.5 & 30.6 & 59 \\
\hline P20 & $3: 2$ & 4 & 2.1 & 0.5 & 6.4 & 51.3 & 10 \\
\hline P21 & 3:2 & 5 & 0.0 & 0.4 & 3.6 & 37.3 & 49 \\
\hline P22 & 3:2 & 6 & 0.5 & 0.5 & 3.4 & 40.0 & 30 \\
\hline P23 & 3:2 & 7 & 0.2 & 0.3 & 3.0 & 41.4 & 27 \\
\hline P24 & 3:2 & 8 & 0.0 & 0.4 & 4.6 & 55.7 & 11 \\
\hline P25 & 3:2 & 9 & 0.6 & 0.0 & 5.4 & 51.9 & 13 \\
\hline P26 & 3:2 & 10 & 0.0 & 0.0 & 6.1 & 57.1 & 8 \\
\hline P27 & $3: 2$ & 11 & 0.0 & 0.2 & 5.0 & 53.1 & 9 \\
\hline P28 & 3:2 & 12 & 0.0 & 0.0 & 4.7 & 55.0 & 8 \\
\hline P29 & $3: 2$ & 13 & 0.0 & 0.0 & 4.4 & 41.8 & 21 \\
\hline P30 & $3: 2$ & 14 & 0.3 & 0.3 & 4.1 & 48.8 & 16 \\
\hline P31 & 3:2 & 15 & 1.1 & 0.6 & 4.5 & 52.0 & 14 \\
\hline P32 & 3:2 & 16 & 2.4 & 0.3 & 5.5 & 55.2 & 12 \\
\hline
\end{tabular}


Table 10. Colonisation, crop cover and soil loss vs. slope, compost and sludge dosage.

\begin{tabular}{|c|c|c|c|}
\hline & Colonisation (plants $/ \mathrm{m}^{2}$ ) & Crop cover (\%) & Soil loss (t/ha-year) \\
\hline Average & 3.63 & 38.26 & 31.41 \\
\hline \multicolumn{4}{|l|}{ Slope } \\
\hline $2: 1$ & $2.49 \mathrm{a}$ & $30.57 \mathrm{a}$ & 37.44 \\
\hline $3: 2$ & $4.78 \mathrm{~b}$ & $45.94 \mathrm{~b}$ & 25.38 \\
\hline \multicolumn{4}{|l|}{ Compost } \\
\hline 0 & 3.43 & $25.64 \mathrm{a}$ & $54.63 \mathrm{a}$ \\
\hline 40 & 3.93 & $42.06 \mathrm{~b}$ & $23.88 \quad \mathrm{~b}$ \\
\hline 60 & 3.59 & $41.82 \mathrm{~b}$ & $23.88 \mathrm{~b}$ \\
\hline 80 & 3.59 & $43.50 \mathrm{~b}$ & $23.25 \mathrm{~b}$ \\
\hline \multicolumn{4}{|l|}{ Sludge } \\
\hline 0 & $2.56 \mathrm{a}$ & $26.56 \quad \mathrm{a}$ & $51.75 \mathrm{a}$ \\
\hline 60 & $4.70 \mathrm{~b}$ & $47.95 \mathrm{~b}$ & $16.25 \mathrm{~b}$ \\
\hline 80 & $3.61 \mathrm{c}$ & $38.59 \mathrm{~b}$ & $29.75 \mathrm{~b}$ \\
\hline 100 & $3.60 \mathrm{c}$ & $39.92 \mathrm{~b}$ & $27.88 \mathrm{~b}$ \\
\hline
\end{tabular}



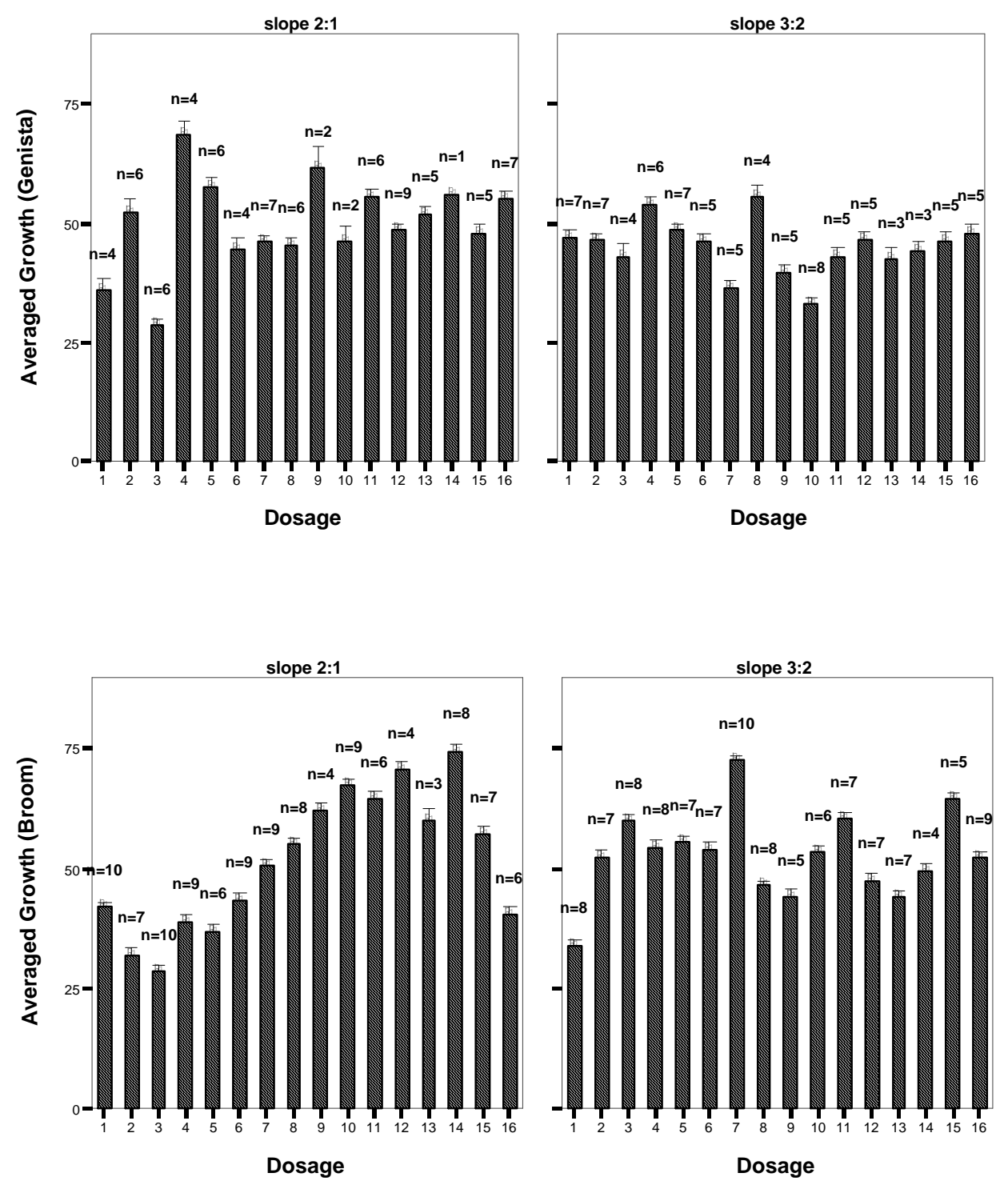

$\left.{ }^{*}\right)$ Bars height denotes the average height per plot. Error bars represent the standard error for the mean, where $\mathrm{n}$ is the number of survival plants.

Figure 1. Averaged Growth for Genista and Broom, in relation to slope and dosage 


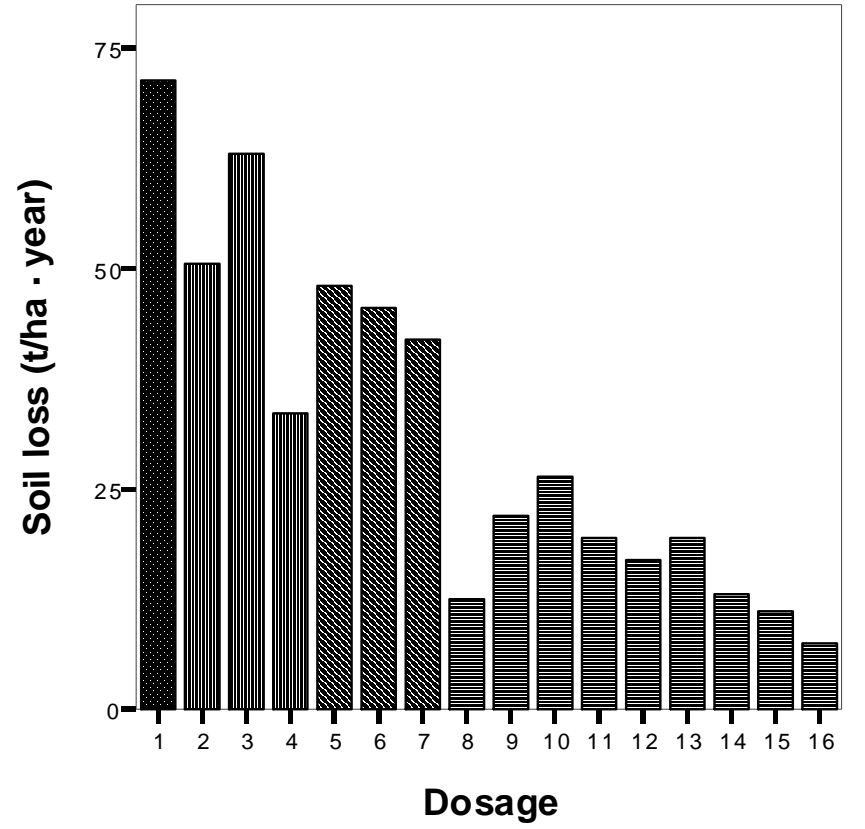

Figure 2. Soil loss in relation to dosage

\section{Type of dosage}

IIIII no sludge or com post

||l|| sludge dos age

… com post dosage

哄 mixtures sludge-com post 